\title{
Residents' Perception of a Collaborative Approach with Artists in Culture-Led Urban Regeneration: A Case Study of the Changdong Art Village in Changwon City in Korea
}

\author{
Yoonjee Baek ${ }^{1}$, Changmu Jung ${ }^{2}$ and Heesun Joo ${ }^{3, *}$ \\ 1 Department of Urban Planning and Design, School of Architecture, Tsinghua University, \\ Beijing 100084, China; novelty47@gmail.com \\ 2 Department of Civil and Environmental Engineering, Seoul National University, Seoul 08226, Korea; \\ plan@snu.ac.kr \\ 3 Department of Urban Engineering, Gyeongsang National University, Jinju 52828, Korea \\ * Correspondence: hsjoo@gnu.ac.kr; Tel.: +82-055-772-1771
}

Citation: Baek, Y.; Jung, C.; Joo, H. Residents' Perception of a

Collaborative Approach with Artists in Culture-Led Urban Regeneration: A Case Study of the Changdong Art Village in Changwon City in Korea. Sustainability 2021, 13, 8320. https:// doi.org/10.3390/su13158320

Academic Editor: Mark Jayne

Received: 18 June 2021

Accepted: 23 July 2021

Published: 26 July 2021

Publisher's Note: MDPI stays neutral with regard to jurisdictional claims in published maps and institutional affiliations.

Copyright: (C) 2021 by the authors. Licensee MDPI, Basel, Switzerland. This article is an open access article distributed under the terms and conditions of the Creative Commons Attribution (CC BY) license (https:// creativecommons.org/licenses/by/ $4.0 /)$.

\begin{abstract}
This study asserts that the higher the degree of artists' and residents' participation in a culture-led renewal project, the higher the level of residents' satisfaction. Engaging artist groups and introducing cultural programs can facilitate building a collaborative network between artists and residents. This paper adopts an experimental study method and defines the experimental and control groups as follows: the experimental group (Changwon city) has relatively high artist participation, and the control group (Sacheon, Gimhae, Miryang cities) have relatively low artist involvement. Multiple regression analysis was conducted utilizing 192 valid survey data in R studio software. The significant variables were compared between the experimental group (Model 1) and the control group (Model 2). As a result, the relative effects of "1. experience (or amount) of residents" participation in urban renewal programs", “2. reflection of residents' opinions", and "3. neighborly trust" on "residents' satisfaction with urban regeneration projects and expected outcomes" was shown to be greater in the experimental group. The result implies that the involvement of cultural entities and the operation of arts programs increase residents' will to participate in renewal projects and to build neighborly trust. Further, collection and reflection of residents' opinions about the renewal works were more smoothly completed when mediated by artist participation and using cultural content.
\end{abstract}

Keywords: culture-led urban regeneration; artist engagement; resident participation; Changdong Art Village; comparative analysis

\section{Introduction}

The trend of utilizing culture and art as a crucial ingredient or tool for urban regeneration has thrived globally. In the 1970s and early 1980s, cultural policy and urban regeneration were merged as a policy panacea, which has been described as culture-led urban regeneration. Many researchers have conducted studies on public art involved in urban regeneration [1], arts-led regeneration [2], and culture-based approaches in urban regeneration [3]. These studies commonly agree that culture-led urban regeneration positively influences the enhancement of local characteristics, stimulates private investments, creates jobs, improves land values, alleviates dilapidated environments, promotes the use of abandoned open spaces, and lowers crime rates [4] (p. 38).

South Korea (hereafter Korea) has established the Special Act on Promotion of and Support for Urban Regeneration since 2013 to achieve sustainable growth of cities and improve the competitiveness of local areas by encouraging public participation and supporting the social, economic, and cultural revitalization of cities [5]. Under the Special Act, the Korean Government has implemented urban regeneration projects, the number of which is increasing every year, adding up to a total of 447 sites, with 46 in 2016, 68 in 
2017, 100 in 2018, 116 in 2019, and 117 in 2020 [6]. The following notable cases are adopted culture-led urban regeneration: the Art Spaces Geumcheon, Mullae, and Seogyo in Seoul; the Totatoga Art Cluster in Busan; the Daein Art Market in Gwangju; and the Changdong Art Village in Changwon [7-16]. These commonly put great emphasis on involving artists and cultural movements for citizens. The Changdong Art Village case has outstanding points in that it builds a collaborative network among diverse participants to gather ideas regarding cultural actions for residents. Based on a cooperative approach, the residents and artists groups could develop diverse cultural activities such as flea markets, small theaters, and street galleries [17] (p. 315).

Merely improving physical facilities and infrastructure is not enough to accomplish culture-led regeneration, and the adoption of the participants' social network should be fully managed [18] (p. 445). Implementing culture-led urban regeneration with the participation and collaboration of key stakeholders is postulated as an essential factor in its social dimension $[19,20]$. Bobadilla et al. [21] highlighted the role of a triad of subjects, including artists, government authorities, and citizens in managing social issues in urban renewal projects and making a long-term network. When participants build an intimate partnership, they tend to deeply understand the process of the renewal project and its contributions [22,23].

According to the collaborative approach developed by Habermas et al. [24] and Healey [25], this study posits that the higher the level of participation of the residents, the higher their satisfaction with the results. As artists participate in urban regeneration projects and program operations, the level of participation of residents increases through the artists' communication and cooperation with residents. Therefore, artist participation has a positive effect on resident satisfaction. The objective of this study is to determine whether artists' participation in culture-led urban regeneration affects residents' satisfaction. We conducted a comparative analysis between an experimental group and a control group. The experimental group (Changwon city) encouraged artist participation and utilized cultural programs for residents during the renewal project, and the control group (Sacheon, Gimhae, Miryang cities) had relatively weak artist participation and cultural movements compared with the experimental group.

\section{Literature Review}

\subsection{Collaborative Approach}

Various terms indicate the notion of a communicative approach in the planning field; for example, comprehensive planning [26,27], transactive planning [28], communicative planning [26,29], and deliberative planning [30,31]. Healey [25] developed the theory of Communicative Action [24] in the urban planning field, which was discussed by Forester [32] and Sager [33]. Innes [34] investigated effective consensus building in the planning process, and political aspects of the planning field were examined by Healey [35].

As for a definition of collaborative approach, Ansell and Gash [36] (p. 544) defined the collaborative approach as "a method of collective decision-making where public agencies and non-state stakeholders directly engage each other in a consensus-oriented deliberative process and that pursues to address public programs or assets". In a study by Emerson et al. [37] (pp. 2-3), it was defined as "the systems and processes of making public policy that involve participants constructively to fulfill a public interest that could not otherwise be achieved". Based on the principal literature, the collaborative approach in this article is defined as the way public subjects cooperate with non-state stakeholders in the decision-making process $[36,38]$. The terms collaborative movement, collaborative network, collaborative mechanism, etc., are regarded in this paper as a synonym of the collaborative approach.

Several essential components of cooperative action have been examined in previous literature [36-40] and recommended for application in institutional contexts, establishing regulations, leadership, building relationships, and outcomes. The component of building relationships includes social ties, communication [40], face-to-face dialogue, shared under- 
standing, trust-building, and principled engagement [36]. Building relations could realize substantive and sustainable positive effects on local revitalization by adding value to or obtaining mutual merits from movements that could not be achieved by individual groups alone $[23,41]$.

\subsection{Culture-Led Urban Regeneration}

Many cities facing stagnant economies have applied culture-led regeneration to rejuvenate depressed areas. This contributes to alleviating urban problems by defining the city's originality and civic pride to the public and even promoting investments [42] (p. 190).

Studies by Landry [43] and Florida [44] introduced the concept of culture-led urban regeneration that creates suitable modern urban lifestyles. A definition of culture-led urban regeneration is " ... a process triggered and/or supported by a wide range of cultural catalysts or regenerators ... " [45] (pp. 40-45). These cultural catalysts indicate artists, organizations or individuals, events, activities, planning regulations, and social trust or flexibility [45,46]. Evans [47] (pp. 966-971) proposed culture as the main catalyst of urban regeneration in that it could realize aims such as physical improvements and social and economic revitalizations $[23,48,49]$. In this vein, the concept of culture-led regeneration in this article refers to arts-based projects pursuing greater participation of local communities and expanding cultural investment to promote social impacts for local groups, including residents $[50,51]$.

\subsection{Artist Participation in Culture-Led Urban Regeneration}

Among the significant subjects involved in culture-led urban regeneration projects, many studies [7-9,44,52-61] have revealed that artists play a vital role in establishing a dynamic milieu of cultural producers and consumers. They implement vital measures to boost creative and cultural industries, which could indirectly improve urban economies [2,3,52]. Thus, the activity of artists is known as "an accelerator for neighborhood transition" [53] (p. 1965), changing dilapidated urban areas into ultra-chic spaces [54] (p. 18). Further, the artists' actions utilizing cultural content could create a sense of belonging, a sense of community, and civic identity by satisfying local communities' demands [55]. Some artists play a significant role, as they are living as community residents [56]; thus, the artists could lead a cultural movement and facilitate residents' involvement [56] and their sense of belonging in a project site [57].

In a study by Florida [44], it is argued that artists' activities drive regional innovation; they state that a city's "creative class" is related to its creativity. It claimed that ideas and talent are important growth engines for all industrial organizations, and creative classes classify talent by occupations of individuals, such as experts, artists, and planners, generating added value through creativity instead of being limited to specific industries. Organizing a creative space in the city is a requirement for promoting arts and cultural activities and achieving urban regeneration. This type of space is referred to as an "artist residency" and involves the renting out of empty houses or unused spaces caused by an urban decline at low rents to artists looking for a home and workspace as a way of reinventing the city. Rius Ulldemolins [58] examined Raval's arts community and commercial network involved in the promotion of the district's brand and reclaimed the district's name, thus reinforcing and consolidating the branding process. Miles and Paddison [59] (p. 838) suggested including local artistic groups in vital decision-making processes of culture-led regeneration projects if these projects aim to involve local communities and their daily cultural lives in the long term. Wang [60] revealed the effect of artist's participation on regional community building and place-making in the Chinese countryside. This study further emphasized the importance of numerous urban experts, companies, and non-profit organizations' participation in artworks aimed at rejuvenating target sites. Pratt [61] explored a representative example of the Tashanzi 798 Art Zone in Beijing, China. Until the 1970s, the military factory, which produced military supplies, moved to the outskirts of 
the city, and the factory building was abandoned in the city. Huge factory buildings were transformed from industrial spaces to art spaces as artists who need a large space at a low rent begin to use them as studios. In 2004, the Chinese Government allocated a huge budget and officially designated the area as a special art zone, establishing it as a symbolic place for contemporary Chinese art, not just a space for artists.

Korean studies that dealt with major parties in culture-led regeneration identified the features of the projects focusing on participants' roles, networks, and degrees of involvement. Chung and Kim [7] identify the features of Art Spaces Geumcheon, Mullae, and Seogyo in Seoul, focusing on the artists' contributions and roles in culture-led urban revitalization projects. The Geumcheon case highlights building communities among artists; the Mullae case has been autonomously managed by local artists; the Seogyo case supports social enterprises and artist groups to ensure financial self-sufficiency. Kim's research [8] on the artists' participation levels classifies the Art Space Mullae in Seoul as a leading private type, the Totatoga in Busan as a leading public type, and the Daein Art Market in Gwangju as a hybrid type. The private leading type features strong relations among the artists and has specific participants who perform central roles in communities; the leading public type, however, needs to have a self-supporting system for the artists to prepare for limited financial support from the government. Park [9] concentrates on the different levels of government intervention in its relationship with artists, residents, and agencies in the Totatoga Art Cluster in Busan, the Daein Art Market in Gwangju, and the Changdong Art Village in Changwon. It was found that the government acts as a director in the Changdong case, serves as a partner in the Gwangju case, and functions as a patron in the Busan case. Park [9] further states that participating artists and planners hardly have a chance to express their creative ideas and opinions for the cultural community due to the government's rigid control, particularly in the director-type role.

In this vein, the term "artists' participation" in this study indicates that artists, as producers or leaders of artistic works, could contribute to building a sense of community with residents and revitalize depressed project sites by engaging in the early stages of the culture-led urban renewal projects.

\subsection{Research Significance and Purpose}

A vast majority of studies on the collaborative network in culture-led urban regeneration have been broadly in agreement that artists play a positive role in local revitalization. However, little research has been devoted to the residents' perspectives and involvement in the collaborative movement of culture-led urban regeneration. For example, García [62] underlines that strong community and active engagement of the public in decision-making processes were implemented to revitalize a place to help residents find distinctive gratification and promote active citizenship in the long run. Similarly, to realize sustainable long-term benefits, it is essential to include the participation and discussion of local groups $[3,23,63]$. In particular, resident involvement plays a crucial role in culture-led regeneration [51]. Although resident's engagement is vital for the collaborative movement in culture-led urban regeneration, there is a dearth of literature investigating residents participation and perspectives. Thus, in the present study, we evaluate residents' roles in the collaborative network and estimate the contributions of culture-led regeneration from the residents' perspectives.

The residents' subjective assessment of the renewal project in their neighborhood implies resident satisfaction with the urban renewal project [64]. A plethora of studies investigated significant elements of resident satisfaction with renewal projects related to physical, social, and economic aspects. For example, the determinants of physical dimension include building conditions, shopping facilities, accessibility to a city center, educational and public services, and neighborhood safety [65-67]. Factors related to the social aspect, including frequent meetings, social cohesion, neighborhood attachment, and social participation, enhanced resident satisfaction with the renewal project [68-70]. Lastly, concerning the economic aspect, numbers of floating population, job opportunities, sales 
growth rate, and land price were suggested as significant elements related to resident satisfaction with the renewal project $[71,72]$. However, there is a dearth of literature on the social aspects of the renewal project from the resident's perspective. To address this gap, we divided residents' engagement and community building into finer variables.

Regarding the research method, previous studies on a collaborative approach and culture-led regeneration have mainly used qualitative and descriptive methods. A few researchers have discussed the effects of culture-led regeneration by conducting empirical analyses. For example, Son [10] investigated significant determinants of local artists' continuous arts activities in the Totatoga Art Cluster in Busan. As a result of Structural Equation Modeling, the program that provides reasonable and stable places to work contributes a positive effect on networks among artists and artistic works, and these strong relations between artists and artistic activities eventually positively affect the improvement of continuous artists' living intentions in the Art Cluster. Park et al. [13] observed the difference in recognition perception between business owners and artists in the Daein Art Market in Gwangju. As a result of partial least squares regression analysis, they found that both groups agreed that by conducting culture-led regeneration and activating artists at the site, there was an influx of visitors to the city. An artist's intention for continuous activities is positively affected by the programs promoting communication among artists, business owners, and residents. Nevertheless, we still lack a refined understanding of the significant variables influencing local revitalization through culture-led regeneration. Therefore, this study attempts to fill the gap by investigating the practical effectiveness of culture-led regeneration by focusing on a collaborative mechanism using empirical analysis.

Many studies investigating culture-led renewal cases identify a specific case or compare two or three projects. When fulfilling comparative studies on culture-led revitalization cases, many study areas are located in different regions or cities with different regional contexts. To our knowledge, a comparative study dealing with cases in a similar regional context is lacking; such a comparison may lead to more fundamental implications and interpretations than those completed in different regions. Hence, in this study, we estimated the effect of culture-led regeneration projects conducted in a Korean administrative district, South Gyeongsang province (Gyeongsangnam-do in Korean), focusing on different artist modes and resident engagements in culture-led revitalization cases. In sum, the interest of this study lies in the effects of culture-led urban regeneration from the residents viewpoint. We focus on ways in which local artists could engage positively within projects to encourage the integration of the opinions of the public, including residents, business owners, and artists. This would, in turn, help urban administrators and policymakers better grasp the culture-led urban regeneration notion and collaborative network in East-Asian countries and assist them in taking necessary action to achieve the desired outcomes in future culture-led urban regeneration projects.

\section{Culture-Led Urban Regeneration in Changwon City}

\subsection{Overview of the Urban Renewal Projects}

The case of Changwon is considered a notable culture-led urban regeneration project in Korea because this project actively encourages the local artists' participation and cultural movements to promote the residents' participation. Therefore, we focus on the renewal projects in Changwon. The old city center of Changwon includes the two administrative neighborhoods (dong in Korean) of the Masanhappo district ( $g u$ in Korean), Changdong and Odongdong. The area thrived as an economic and commercial center from the 1760s to the early 1990s. However, the urban center dramatically declined due to the restructuring of industries from the end of the 1990s. To deal with this problem, several actions utilizing culture and art as essential ingredients for urban center regeneration have been discussed and implemented since the early 2000s $[14,15]$.

The local government of Changwon city progresses continuous culture-led urban regeneration projects in the old city. The project site is illustrated in Figure 1. The first urban renewal project was announced by the central Korean Government and conducted from 
2011 to 2014. As a part of this project, the Changdong Art Village has been developed since May 2012. It reuses about 60 empty spaces as working areas for local artists in the old city center to rejuvenate the deteriorated area. This renewal project also focused on the local residing artists and diverse activities in the city center. The local government of Changwon subsidized $60 \%$ of the rent, and the building owners assisted with the remaining $40 \%$ to lessen the financial burden for the local artists $[15,16,73,74]$.

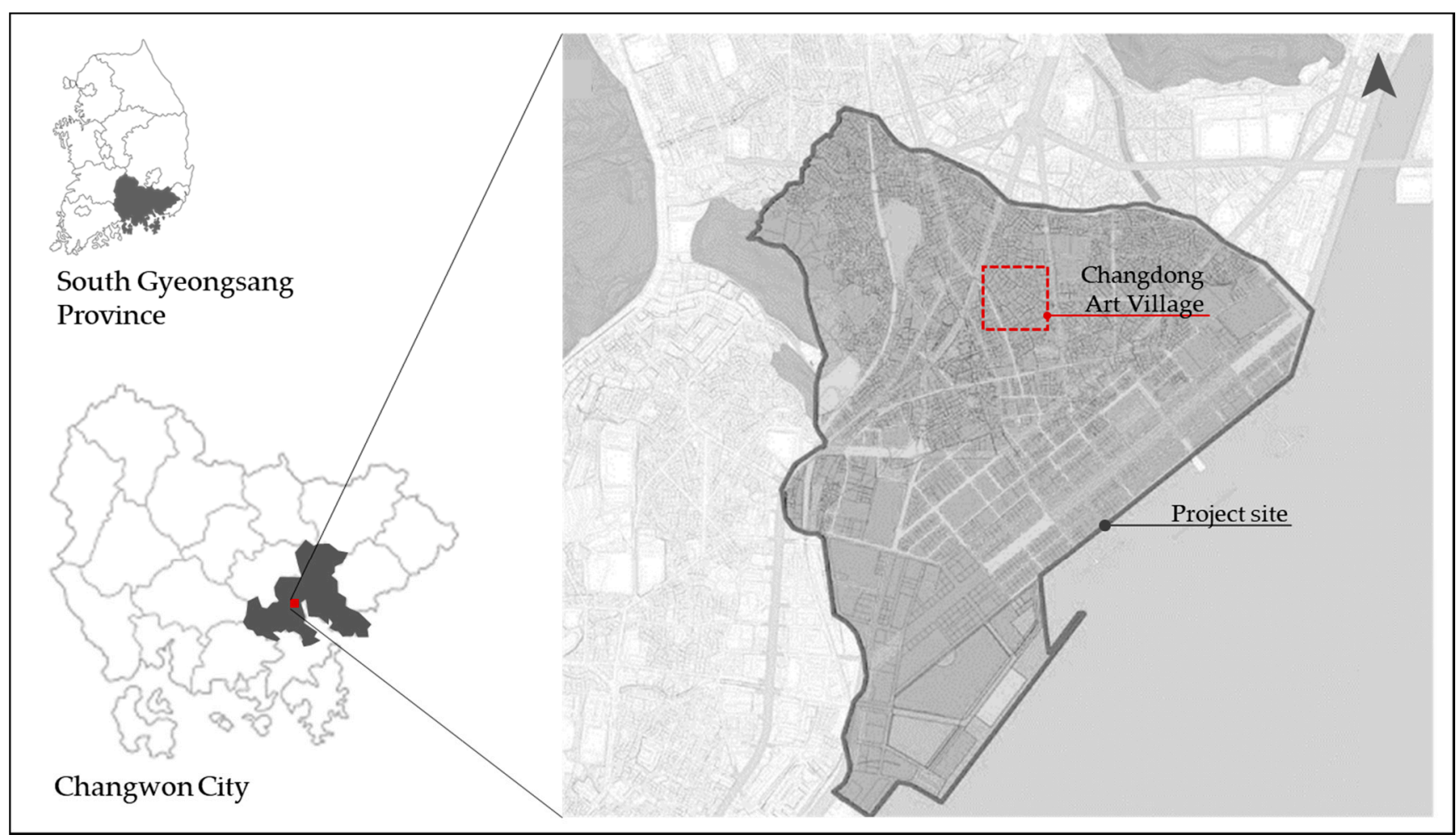

Figure 1. The Changwon urban regeneration project site. Source: designed by the authors in 2021.

The second urban renewal project was implemented from 2014 to 2017 at the urban center. This project aimed to revitalize the local economy and community and attract people to visit the city [75]. The outline of this project is presented in Table 1. In this renewal project, several cultural programs and actions were proposed to strengthen artists' abilities and local communities (Table 2). The primary content included: (1) strengthening artists' abilities and networks, (2) communicating with residents and business owners, (3) organizing diverse cultural programs, and (4) managing operational systems for the Art Village [76] (p. 143). In sum, it established the continuity of plans utilizing culture and art in urban renewal projects to realize sustainable and continuous developments in the cultural and artistic field. A total of 53 artists participate in the Art Village, where 62 units have been reused as working spaces in 2021. The local artists play a vital role in the development of cultural programs for residents and the public. 
Table 1. Overview of the Changwon urban regeneration project.

\begin{tabular}{cl}
\hline Category & \multicolumn{1}{c}{ Content } \\
\hline Type & Support/renewal of neighborhoods \\
\hline Site & $\begin{array}{l}\text { Seongho, Dongseo, and Odong neighborhoods of Masan-happo district, } \\
\text { Changwon city, South Gyeongsang province }\end{array}$ \\
\hline Area & $1,780,000 \mathrm{~m}^{2}$ \\
\hline Period & $2014-2017(4$ years) \\
Budget & $\begin{array}{l}\text { 20 billion KRW } \\
\text { (national expenditure }=10 \text { billion KRW, local expenditure }=10 \text { billion } \\
\text { KRW) }\end{array}$ \\
\hline Source: reorganized by the authors based on Joo et al. [75] (pp. 8-9).
\end{tabular}

Table 2. Overview of the program for artists.

\begin{tabular}{cl}
\hline \multicolumn{1}{c}{ Category } & \multicolumn{1}{c}{ Content } \\
\hline Site & Changdong Art Village \\
\hline Period & 2015-2017 (3 years) \\
Content & $\begin{array}{l}\text { (1) Strengthening artists' abilities and network } \\
\text { (2) Communicating with residents and business owners } \\
\text { (3) Organizing diverse cultural programs } \\
\text { (4) Managing operational systems for the Art Village }\end{array}$ \\
\hline Organizer & $\begin{array}{l}\text { Ministry of Land, Infrastructure and Transport (MOLIT) } \\
\text { The local government of Changwon city }\end{array}$ \\
\hline Budget & $\begin{array}{l}\text { 1 billion KRW (national expenditure = 500 million KRW, provincial } \\
\text { expenditure }=150 \text { million KRW, city expenditure = 350 million KRW) * }\end{array}$ \\
\hline $\begin{array}{l}{ }^{*} \text { Note: Half of the budget is a matching fund with state subsidies. The South Gyeongsang province paid 15\% of } \\
\text { the budget and the 35\% of the budget was paid by Changwon city. Source: reorganized by the authors based on } \\
\text { the revitalization plan of Changwon urban regeneration project [76] (pp. 146, 170). }\end{array}$
\end{tabular}

\subsection{Collaborative Network between Artists and Residents}

The Changwon renewal project has outstanding points in that it builds a collaborative network among diverse participants to gather ideas regarding cultural actions for residents. The collaborative system is shown in Figure 2. Most of the artists are from Changwon; therefore, they have a sense of belonging and attachment to the city and show a strong willingness to revitalize the area. The related parties, the local artist groups, design companies, the residents, and the local government, had several seminars on distilling art programs for the residents at the end of 2014. In addition, frequent interviews and communications with artist groups were conducted. The artists suggested the necessity of diverse cultural programs to enable the residents to participate in the cultural activities with the artist groups [76] (pp. 67-74). To develop the cultural programs, the local artist groups cooperated with the resident groups, students, and professionals from the architecture and urban planning fields. As a result, the implementation of various cultural programs and events could be facilitated in the Changwon renewal case by motivating residents and artists' participation in the cultural programs [76] (pp. 146-149).

In sum, the policy of creating a cultural district using artists corresponds to a representative culture-based urban regeneration strategy. It stimulates creative activities by attracting artists to stagnant downtown areas. Thus, it is a strategy to revitalize the region by operating educational programs and holding festivals (Table 3). Recently, many artists have participated in urban regeneration projects. Changdong Art Village actively participated in the urban regeneration project by providing both residences and studios for artists to live in so that they could work while staying in the area and relocated artists to live in the area. In this case, artists participated in urban regeneration to actively encourage environmental improvement and resident participation in the project. 


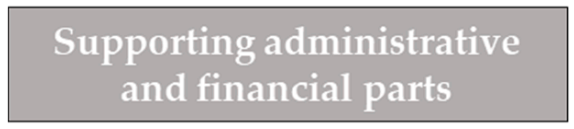

Developing art and culture programs

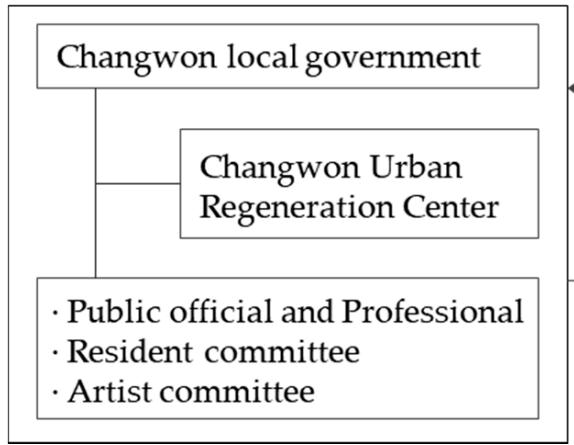

\begin{tabular}{|c|c|c|}
\hline $\begin{array}{r}\text { Informing major } \\
\text { issues, opinions }\end{array}$ & $\begin{array}{l}\text { Resident } \\
\text { groups }\end{array}$ & $\begin{array}{l}\cdot \text { Seongho-dong } \\
\cdot \text { Dongseo-dong } \\
\text { - Odong-dong }\end{array}$ \\
\hline $\begin{array}{l}\text { Regular meetings } \\
\text { Providing feedback }\end{array}$ & \multicolumn{2}{|r|}{ Expert groups } \\
\hline $\begin{array}{l}\text { Notifying } \\
\text { information and }\end{array}$ & \multicolumn{2}{|c|}{$\begin{array}{ll}\text { Artist } & \cdot \text { The Art Village } \\
\text { groups } & \cdot \text { The Artist Residency }\end{array}$} \\
\hline guidelines & \multicolumn{2}{|c|}{ University students } \\
\hline
\end{tabular}

Figure 2. Collaborative network in the Changwon project. Source: reorganized by the authors based on the revitalization plan of Changwon urban regeneration project [76] (p.148).

Table 3. Cultural programs for citizens.

\begin{tabular}{|c|c|}
\hline Category & Content \\
\hline $\begin{array}{c}\text { Art } \\
\text { School }\end{array}$ & $\begin{array}{l}\text { Cultural and art classes for citizen } \\
\text { Providing } 10-12 \text { courses in every the first/second half of the year } \\
\text { The number of people in a course is } 10-15 \text { people } \\
\text { (e.g.,) the classes in the first half of } 2021 \text { : barista, harmonica, calligraphy, } \\
\text { metalcraft, photography, Western painting, Argentine tango, etc. }\end{array}$ \\
\hline Art Ground & $\begin{array}{l}\text { Artists leading daily classes for citizens or visitors who can make a } \\
\text { diverse stuff } \\
\text { (e.g.,) the classes in 2021: wood cutting board, card wallet, light fixture, } \\
\text { accessories, flowerpot, etc. }\end{array}$ \\
\hline Cultural Event & $\begin{array}{l}\text { Concert of celebrating the Village opening (May), culture art festival for } \\
\text { children (May), } \\
\text { The Art Village's Culture and Art Festival (October/November), } \\
\text { flea market }\end{array}$ \\
\hline Others & $\begin{array}{l}\text { The Art Village Tour Program } \\
\text { Collaboration with the local culture center ((e.g.,) the artists had art } \\
\text { classes(calligraphy, painting, modern art, etc.) in the Culture Hall in the } \\
\text { local department store) }\end{array}$ \\
\hline
\end{tabular}

\section{Research Method}

\subsection{Analytical Framework}

This study focused on the influence of artist involvement on the collaborative network and residents' satisfaction with culture-led urban regeneration. To evaluate whether artist participation promotes the residents' active involvement in culture-led renewal projects or not, we adopted a method of experimental study by using two groups, an experimental group and a control group, and comparing differences between the two groups. A similar approach is used in the social science field, whereas, to our knowledge, little literature on the collaborative approach in culture-led regeneration has been addressed using the experimental method. Based on this, the analytical framework in Figure 3 was developed. 


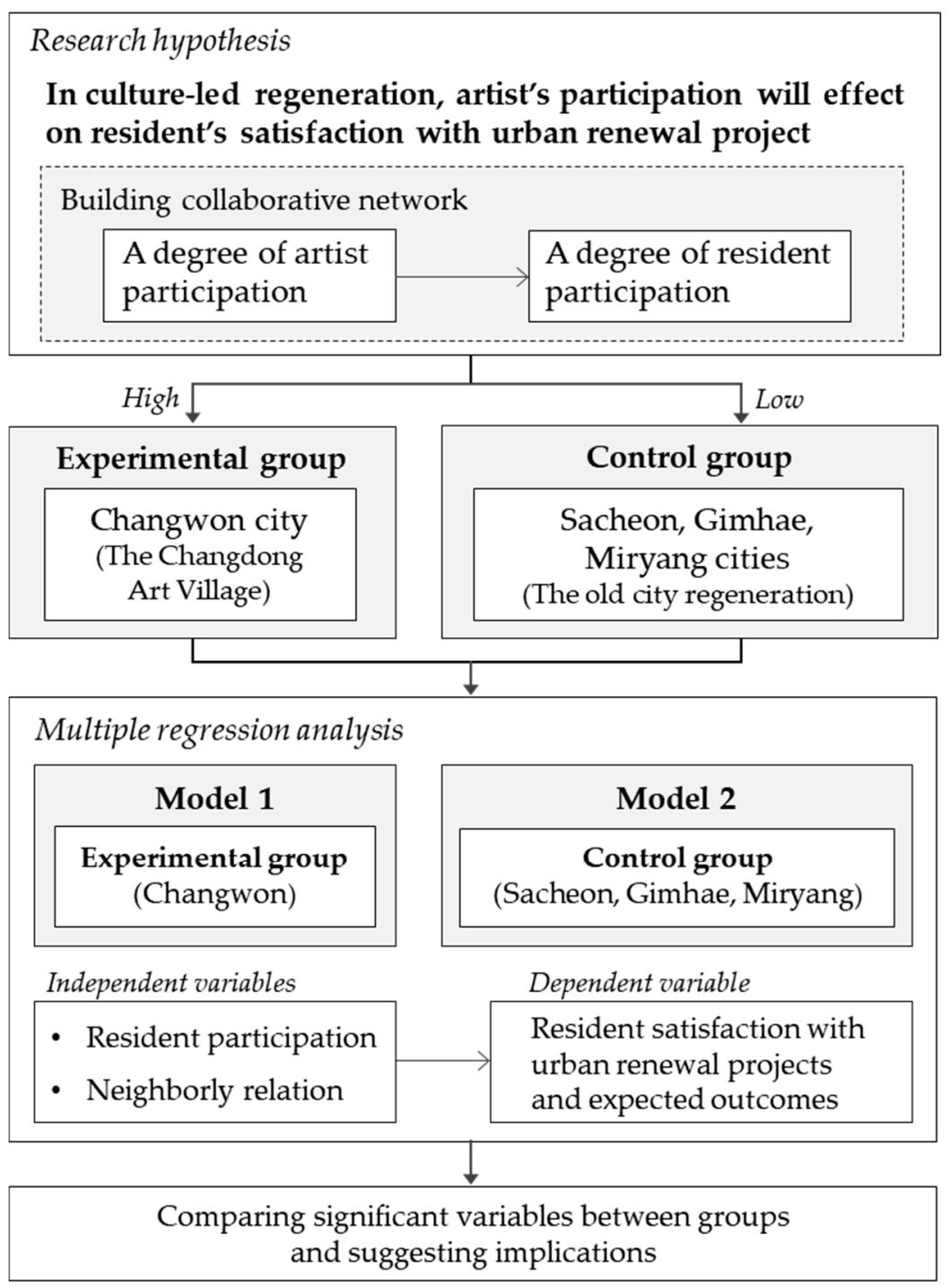

Figure 3. Analytical framework. Source: designed by the authors in 2021.

The experimental group indicates the Changdong Art Village project in Changwon city, where the local artists and residents are deeply engaged and diverse cultural programs are managed. The first multi-regression model (hereafter Model 1) is estimated to analyze the data from Changwon city. For the control group, some old city regeneration cases in South Gyeongsang Province are selected, which are urban renewal cases in Sacheon, Gimhae, and Miryang cities. The second multi-regression model (hereafter Model 2) is estimated to utilize the data from the control group where the opportunities for communication between the residents and artists are relatively few. By conducting a comparative analysis between Model 1 and Model 2, we examine the effects between the levels of artist engagement and the residents' satisfaction with culture-led urban regeneration.

\subsection{Selecting the Control Group}

Several culture-led urban regeneration projects have been implemented in South Gyeongsang province following the pilot project in Changwon from 2014 to 2017. These projects commonly aim to rejuvenate old city centers. Each case has different degrees of artist and/or resident involvement and portion of art programs in the projects. Therefore, by conducting an empirical analysis of culture-led urban regeneration based on the levels of local artist and resident engagement, significant practical implications could be revealed. The control group for this study was defined according to (1) the year selected as an 
urban regeneration site from the central government, (2) the type of project, and (3) the progress rate of the project. As a result, the final cases (selected year, type, period) are as follows: Sacheon (2017, support/renewal of city centers, 2018-2022), Gimhae (2017, support/renewal of city centers, 2018-2022), and Miryang (2017, support/renewal of neighborhoods, 2018-2021). Figure 4 and Table 4 show the selected control group.

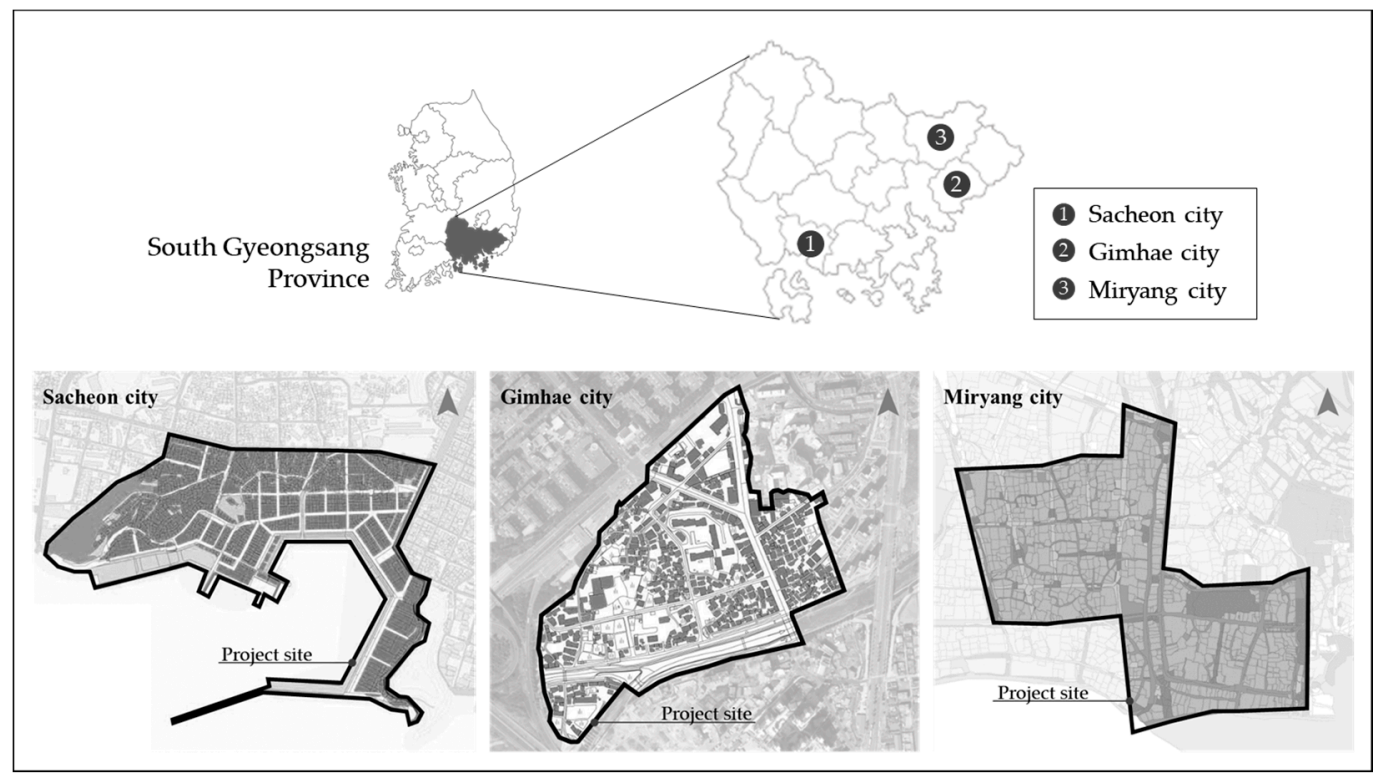

Figure 4. The renewal project sites in Sacheon, Gimhae, and Miryang cities. Source: designed by the authors in 2021.

Table 4. Overview of the urban renewal projects in the control group.

\begin{tabular}{|c|c|c|c|}
\hline & Sacheon & Gimhae & Miryang \\
\hline Type & \multicolumn{2}{|c|}{ Support/renewal of city centers } & $\begin{array}{l}\text { Support/renewal of } \\
\text { neighborhoods }\end{array}$ \\
\hline Location & $\begin{array}{l}\text { Dongseo, Seongu, and } \\
\text { Dongseogeum } \\
\text { neighborhoods, Sacheon } \\
\text { city, South } \\
\text { Gyeongsang province }\end{array}$ & $\begin{array}{l}\text { Mugye neighborhood, } \\
\text { Gimhae city, South } \\
\text { Gyeongsang province }\end{array}$ & $\begin{array}{c}\text { Naei and Naeil } \\
\text { neighborhoods, Miryang } \\
\text { city, South } \\
\text { Gyeongsang province }\end{array}$ \\
\hline Area & $291,829 \mathrm{~m}^{2}$ & $199,600 \mathrm{~m}^{2}$ & $147,000 \mathrm{~m}^{2}$ \\
\hline Period & 2018-2022 (5 years) & 2018-2022 (5 years) & 2018-2021 (4 years) \\
\hline Budget & $\begin{array}{c}25 \text { billion KRW } \\
\text { (national } \\
\text { expenditure } 15=\text { billion } \\
\text { KRW, local } \\
\text { expenditure }=10 \text { billion } \\
\text { KRW) }\end{array}$ & $\begin{array}{c}25 \text { billion KRW } \\
\text { (national } \\
\text { expenditure }=15 \text { billion } \\
\text { KRW, local } \\
\text { expenditure }=10 \text { billion } \\
\text { KRW) }\end{array}$ & $\begin{array}{c}16.7 \text { billion KRW } \\
\text { (national } \\
\text { expenditure }=10 \text { billion } \\
\text { KRW, local } \\
\text { expenditure }=6.7 \text { billion } \\
\text { KRW) }\end{array}$ \\
\hline
\end{tabular}

Source: reorganized by the authors based on Joo et al. [75] (pp. 20-28).

\subsection{Measurement Instrument}

The data used in this study are from an on-site survey conducted in the old urban centers of the four cities: Changwon, Sacheon, Gimhae, and Miryang. Structured questionnaires were reorganized based on questionnaires used in previous studies [71,72,77-79]. All questionnaires were administrated face-to-face because the site population typically comprises older adults. Structured questionnaire interviews were conducted among residents of the research sites for 16 days, from late April to mid-May 2019. A total of 192 valid samples are used for the quantitative analysis: Changwon $(n=50,26 \%)$, Miryang $(n=56$, 
$29.2 \%)$, Sacheon $(n=55,28.6 \%)$, and Gimhae $(n=31,16.1 \%)$. Each variable was measured on a four-point Likert scale, and Table 5 provides further details.

Table 5. Measurement of variables.

\begin{tabular}{|c|c|c|c|c|}
\hline \multicolumn{2}{|c|}{ Variable } & \multicolumn{2}{|c|}{ Questionnaire Item } & Scale \\
\hline \multirow{2}{*}{$\begin{array}{l}\text { Dependent } \\
\text { variable }\end{array}$} & \multirow{2}{*}{$\begin{array}{c}\text { Resident } \\
\text { satisfaction and } \\
\text { expectation with } \\
\text { the urban } \\
\text { regeneration project }\end{array}$} & \multicolumn{2}{|c|}{$\begin{array}{l}\text { Please indicate your opinion on the level of satisfaction with the } \\
\text { urban renewal project in your neighborhood. }\end{array}$} & $\begin{array}{l}\text { (1) Extremely } \\
\text { unsatisfied (4) } \\
\text { Extremely satisfied }\end{array}$ \\
\hline & & \multicolumn{2}{|c|}{$\begin{array}{l}\text { Please indicate your expectations(in living environment, } \\
\text { economic, neighborly relation, urban regeneration project) for the } \\
\text { ongoing urban renewal project in your neighborhood. }\end{array}$} & $\begin{array}{l}\text { (1) Extremely } \\
\text { unexpected } \sim \text { (4) } \\
\text { Extremely expected }\end{array}$ \\
\hline \multirow{5}{*}{$\begin{array}{l}\text { Independent } \\
\text { variables }\end{array}$} & \multirow{3}{*}{$\begin{array}{l}\text { Resident } \\
\text { participation in the } \\
\text { urban } \\
\text { regeneration project }\end{array}$} & $\begin{array}{l}\text { Experience(or amount) } \\
\text { of participation in } \\
\text { urban } \\
\text { renewal programs }\end{array}$ & $\begin{array}{l}\text { How many times have you } \\
\text { participated in urban renewal } \\
\text { programs (including public } \\
\text { hearing/discussion, residents' council, } \\
\text { education, seminar) on the ongoing } \\
\text { project in your neighborhood? }\end{array}$ & $\begin{array}{l}\text { (1) No, (2) Yes } \\
\text { (1) } \mathrm{No}=0 \text {, (2) } \mathrm{Yes}=1 \text { ) }\end{array}$ \\
\hline & & $\begin{array}{l}\text { Level of the resident's } \\
\text { opinions reflected in } \\
\text { the project }\end{array}$ & $\begin{array}{l}\text { Please indicate your general opinion } \\
\text { on the degree of the residents' opinion } \\
\text { reflected on the ongoing urban } \\
\text { renewal project in your neighborhood. }\end{array}$ & $\begin{array}{l}\text { (1) Extremely low } \\
\text { (4) Extremely high }\end{array}$ \\
\hline & & $\begin{array}{l}\text { Need for urban } \\
\text { renewal projects }\end{array}$ & $\begin{array}{l}\text { Please indicate your general opinion } \\
\text { on the need to implement an urban } \\
\text { renewal project in your neighborhood. }\end{array}$ & $\begin{array}{c}\text { (1) Extremely } \\
\text { unnecessary (4) } \\
\text { Extremely necessary }\end{array}$ \\
\hline & Neighborly relation & Neighborly trust & $\begin{array}{l}\text { What is your subjective trust level } \\
\text { with neighborly relations in } \\
\text { your neighborhood? }\end{array}$ & $\begin{array}{c}\text { (1) Extremely } \\
\text { unreliable (4) } \\
\text { Extremely reliable }\end{array}$ \\
\hline & $\begin{array}{l}\text { Living } \\
\text { condition }\end{array}$ & $\begin{array}{l}\text { Level of satisfaction } \\
\text { with living } \\
\text { environments }\end{array}$ & $\begin{array}{l}\text { How satisfied are you with the overall } \\
\text { living environment of your current } \\
\text { neighborhood as compared with } \\
\text { surrounding neighborhoods? }\end{array}$ & $\begin{array}{l}\text { (1) Extremely } \\
\text { unsatisfied (4) } \\
\text { Extremely satisfied }\end{array}$ \\
\hline
\end{tabular}

We observed how local artists' participation influences local community building and resident satisfaction with culture-led renewal projects. In both the experimental (Changwon city) and control groups (Sacheon, Gimhae, Miryang cities), the culture and art applied in urban renewal projects were already completed or ongoing at the time of this study. Thus, it is presumed that the residents had both satisfaction and future expectations for the urban renewal projects. As suggested by Nachmias and Palen [80], expected neighborhood satisfaction is correlated with a resident's intention to move or renovate their house; therefore, it is assumed that residents' satisfaction and expectations with urban regeneration projects are associated with their willingness to stay in their current neighborhood and the possibility of their engagement in future or current renewal programs [81-84].

We concentrated on the artists' and residents' participation and relationship-building among them in culture-led urban renewal projects. Based on the local artists' engagement in the collaborative mechanism, it would realize more positive and progressive resident participation and community building. Numerous previous studies demonstrated ways to estimate residents' participation and community building; however, relatively little attention has been paid to dividing the residents' involvement and social network building into finer variables $[70,85]$. To address this gap, this study specified residents' engagement and community building using the following variables: (1) experience (or amount) of participation in urban renewal programs, (2) level of residents' opinions reflected in the project, (3) residents' will about urban regeneration projects, and (4) neighborly trust. These variables are expected to influence residents' satisfaction and expectation with urban 
renewal projects. In addition, culture-led urban renewal projects trigger improvements in physical, economic, and social dimensions and promote comprehensive advancements at the project sites. Therefore, the variable of residents' satisfaction with their overall neighborhood environment is reflected to estimate its influence on resident satisfaction and expectation with urban renewal projects.

\subsection{Research Hypotheses}

To test the main hypothesis, sub-hypotheses were set up in this study. The main hypothesis proposes that areas with the more active participation of artists and residents are likely to show higher resident satisfaction with regeneration projects (Table 6).

Table 6. Research hypotheses.

\begin{tabular}{|c|c|c|c|}
\hline \multicolumn{2}{|c|}{ Variables } & $\begin{array}{c}\text { Comparison } \\
\text { between Groups * }\end{array}$ & Hypothesis \\
\hline \multirow{3}{*}{$\begin{array}{c}\text { Resident } \\
\text { participation in } \\
\text { urban } \\
\text { regeneration } \\
\text { project }\end{array}$} & $\begin{array}{l}\text { Experience (or amount) of } \\
\text { participation in urban } \\
\text { renewal programs }\end{array}$ & \multirow{4}{*}{$\begin{array}{l}\text { Experimental group } \\
>\text { Control group }\end{array}$} & Hypothesis 1 \\
\hline & $\begin{array}{l}\text { Level of the resident's } \\
\text { opinions reflected in } \\
\text { the project }\end{array}$ & & Hypothesis 2 \\
\hline & $\begin{array}{l}\text { Need for urban renewal } \\
\text { projects }\end{array}$ & & Hypothesis 3 \\
\hline $\begin{array}{l}\text { Neighborly } \\
\text { relation }\end{array}$ & Neighborly trust & & Hypothesis 4 \\
\hline
\end{tabular}

* Note: the experimental group means Changwon city and the control group indicates Sacheon, Gimhae, and Miryang cites.

Hypothesis 1. The effect of "experience (or amount) of participation in urban renewal programs" on "resident satisfaction with urban regeneration projects/expected outcomes $(y)$ " will be higher in the experimental group than in the control group.

Hypothesis 2. The effect of "reflection of residents' opinions on regeneration projects" on "resident satisfaction with urban regeneration projects/expected outcomes $(y)^{\prime \prime}$ will be higher in the experimental group than in the control group.

Hypothesis 3. The effect of "residents' will about urban regeneration projects" on "resident satisfaction with urban regeneration projects/expected outcomes $(y)$ " will be higher in the experimental group than in the control group.

Hypothesis 4. The effect of "neighborly trust" on "resident satisfaction with urban regeneration projects/expected outcomes (y)" will be higher in the experimental group than in the control group.

\section{Empirical Results}

Data from 192 questionnaires were used in this analysis. A description of the respondents' social-demographic characteristics is shown in Table A1 (Appendix A). Regarding gender, $41.3 \%$ of respondents were male, and $58.7 \%$ were female. Regarding age groups, participants in their 40 s and 50s made up the largest portion at $28.1 \%$. In the ownership and type of property, $67.2 \%$ of respondents lived in their own house, $13.8 \%$ paid rent for a house, and $43 \%$ resided in apartments, while $26.5 \%$ lived in detached houses. Regarding household members, $43.4 \%$ lived with four family members, while $13.8 \%$ of respondents lived alone. The average length of residence was 3.2 years.

Descriptive statistical analysis was conducted for major variables; the outcomes are presented in Table 7. The descriptive statements about the key variables were rated on a 4 -point Likert scale, ranging from $1=$ extremely disagree to $4=$ extremely agree. The average score of variables representing "resident satisfaction and the expectation with urban renewal project" was relatively high as follows: "expectations for improving 
living environments" was 3.1, "expectations for improving the local economy" was 3.0, "expectations for improving neighborly relations" was 3.0, "expectations for the result of the renewal project" was 3.0, and "satisfaction with urban renewal projects" was 2.7. In addition, the average score of variables representing "resident perception with urban renewal project" showed relatively high values; for example, "level of satisfaction with living environments" was 3.7, "need for urban renewal projects" was 3.5, "level of the resident's opinions reflected in the project" was 2.8 , "neighborly trust" was 2.8 . The average "experience (or amount) of participation in urban renewal programs" was 1.4, which stated that the respondents participated in at least a program for the resident on average.

Table 7. Descriptive statistics of major variables.

\begin{tabular}{|c|c|c|c|c|}
\hline Variables & Average & $\begin{array}{l}\text { Standard } \\
\text { Deviation }\end{array}$ & Min. & Max. \\
\hline Expectations for improving living environments & 3.1 & 0.7 & 1 & 4 \\
\hline Expectations for improving the local economy & 3 & 0.7 & 1 & 4 \\
\hline Expectations for improving neighborly relations & 3 & 0.7 & 1 & 4 \\
\hline Expectations for the result of the renewal project & 3 & 0.7 & 1 & 4 \\
\hline Satisfaction with urban renewal projects & 2.7 & 0.8 & 1 & 4 \\
\hline Level of satisfaction with living environments & 3.7 & 1.2 & 1 & 4 \\
\hline Need for urban renewal projects & 3.5 & 0.6 & 2 & 4 \\
\hline $\begin{array}{l}\text { Level of the resident's opinions reflected } \\
\text { in the project }\end{array}$ & 2.8 & 0.8 & 1 & 4 \\
\hline Neighborly trust & 2.8 & 0.7 & 1 & 4 \\
\hline $\begin{array}{l}\text { Experience (or amount) of participation } \\
\text { in urban renewal programs }\end{array}$ & 1.4 & 1.7 & 1 & 4 \\
\hline
\end{tabular}

Subsequently, factor analysis was carried out to define the dependent variable, as shown in Table A2 (Appendix B). Cronbach's alpha was used to test the reliability of selected scales. The Cronbach's alpha produced 0.89 (above 0.7), and the scale was deemed reliable. Specifically, five variables from the survey were grouped: (1) satisfaction with urban renewal projects, (2) expectations for improving living environments, (3) expectations for improving local economy, (4) expectations for improving neighborly relations, and (5) expectations for the renewal project. Finally, a correlation analysis was conducted to explore the relationships between the dependent variables and the independent variables utilizing a Pearson's correlation. The results are illustrated in Table A3 (Appendix C).

\section{Regression Results}

Multiple regression analysis was performed using R Studio software to evaluate "resident satisfaction and expectations of urban renewal projects" in the experimental and control groups. A backward method was adopted. Table 8 shows the results of the estimated multiple regression model. Multiple regressions were performed independently to identify the differences between Models 1 and 2. There was a noticeable difference between what the two groups considered essential about the dependent variable of "resident satisfaction and expectation with urban renewal projects." 
Table 8. Results of multi-regression models.

\begin{tabular}{|c|c|c|c|c|c|c|c|}
\hline & \multirow{3}{*}{ Variables } & \multicolumn{3}{|c|}{ Model 1} & \multicolumn{3}{|c|}{ Model 2} \\
\hline & & B & $\beta$ & & B & $\beta$ & \\
\hline & & SE & $t(p)$ & & SE & $t(p)$ & \\
\hline \multirow{6}{*}{$\begin{array}{l}\text { Resident } \\
\text { participation } \\
\text { in the urban } \\
\text { renewal } \\
\text { project }\end{array}$} & \multirow{2}{*}{ Need for urban renewal projects } & 0.235 & 0.192 & & 0.274 & 0.283 & \\
\hline & & 0.089 & 2.654 & $* *$ & 0.067 & 4.092 & *** \\
\hline & \multirow{2}{*}{$\begin{array}{l}\text { Level of the resident's opinions } \\
\text { reflected in the project }\end{array}$} & 0.461 & 0.573 & & 0.458 & 0.549 & \\
\hline & & 0.064 & 7.190 & $* * *$ & 0.056 & 8.170 & $* * *$ \\
\hline & \multirow{2}{*}{$\begin{array}{l}\text { Experience (or amount) of } \\
\text { participation in urban renewal programs }\end{array}$} & 3.722 & 0.220 & & 0.760 & 0.065 & \\
\hline & & 1.187 & 3.135 & $* * *$ & 0.834 & 0.912 & \\
\hline \multirow{2}{*}{$\begin{array}{l}\text { Neighborly } \\
\text { relation }\end{array}$} & \multirow{2}{*}{ Neighborly trust } & 0.162 & 0.204 & & 0.120 & 0.134 & \\
\hline & & 0.060 & 2.695 & $* *$ & 0.063 & 1.913 & * \\
\hline \multirow{6}{*}{$\begin{array}{l}\text { Living } \\
\text { condition }\end{array}$} & \multirow{2}{*}{$\begin{array}{l}\text { Level of satisfaction with living } \\
\text { environments }\end{array}$} & 0.346 & 0.385 & & 0.032 & 0.047 & \\
\hline & & 0.071 & 4.900 & $* * *$ & 0.046 & 0.693 & \\
\hline & \multirow{2}{*}{ Intercept } & -19.87 & 0 & & 7.182 & 0.000 & \\
\hline & & 9.197 & -2.161 & $* *$ & 6.069 & 1.183 & \\
\hline & $R\left(A d j-R^{2}\right)$ & \multicolumn{3}{|c|}{$0.846(0.822)$} & \multicolumn{3}{|c|}{$0.581(0.561)$} \\
\hline & F-statistic $(p)$ & \multicolumn{3}{|c|}{$35.21^{* * *}$} & \multicolumn{3}{|c|}{$29.40 * * *$} \\
\hline
\end{tabular}

First, as a result of Model 1, the positive effects of proactive participation of local artists are shown. Multicollinearity, or the inter-association among independent variables, was identified by the variance inflation factor measuring 1.025 to $1.320(\leq 10)$. Therefore, as values of all the variables in Model 1 satisfied the standard values, the matter of multicollinearity between the independent variables is regarded as absent. The modified R-squared (adj- $\mathrm{R}^{2}$ ) value for the model was 0.822 . Analysis of variance (ANOVA) measured an $\mathrm{F}$ value of 35.21 with $p=0.000(<0.01)$, therefore informing the validity of the multiple linear regression model (Model 1). The beta coefficients observed to clarify the significant variables and their influences indicated; (1) level of residents' opinions reflected in the project $(\beta=0.573)$, (2) level of satisfaction with living environments $(\beta=0.385)$, (3) experience (or amount) of participation in urban renewal programs $(\beta=0.220)$, (4) neighborly trust $(\beta=0.204)$, and (5) need for urban renewal projects $(\beta=0.192)$.

Second, Model 2 was estimated by dealing with culture-led renewal projects in the control group, which revealed relatively passive movements of local artists. The variance inflation factor presenting 1.143 to $1.281(\leq 10)$ was used to identify multicollinearity. Thus, as the values of all the variables of the analysis model met standard values, the problem of multicollinearity between the independent variables was deemed absent. The adj- $\mathrm{R}^{2}$ value for the model is 0.561 . The $\mathrm{F}$ value is 29.40 with $p=0.000(<0.01)$, which points to the validity of the multiple linear regression model (Model 2). Beta weights were calculated to identify the significant variables and their impacts; the results are presented in the following order: (1) level of the resident's opinions reflected in the project $(\beta=0.549)$, (2) need for urban renewal projects $(\beta=0.283)$, and (3) neighborly trust $(\beta=0.134)$.

A notable difference between the experimental and control groups is related to the degree of artist participation in culture-led urban regeneration. The Changwon case achieved a high level of artist participation and established various art programs for residents, which, in turn, led to an increase in citizens' participation and improvement in their interest by continuously operating arts and cultural programs led by artists. The hypotheses were tested based on the analysis results above to determine whether this characteristic had a significant positive effect on residents' satisfaction with urban regeneration projects and expected outcomes in the experimental group. Based on the comparison of standardized 
coefficients ( $\beta$ ) of significant variables in each model, Hypotheses 1, 2, and 4 are supported, and Hypothesis 3 is not supported (Table 9).

Table 9. Significant variables and hypotheses testing.

\begin{tabular}{|c|c|c|c|c|c|c|c|}
\hline \multirow{2}{*}{\multicolumn{2}{|c|}{ Significant Variables }} & \multirow{2}{*}{\multicolumn{2}{|c|}{$\begin{array}{c}\text { Model } 1 \\
\beta(p)\end{array}$}} & \multirow{2}{*}{\multicolumn{2}{|c|}{$\begin{array}{c}\text { Model } 2 \\
\beta(p)\end{array}$}} & \multirow{2}{*}{$\begin{array}{c}\text { Comparison } \\
\text { between Groups }\end{array}$} & \multirow[t]{2}{*}{ Hypothesis Testing } \\
\hline & & & & & & & \\
\hline \multirow{3}{*}{$\begin{array}{c}\text { Resident } \\
\text { participation in } \\
\text { urban } \\
\text { regeneration } \\
\text { project }\end{array}$} & $\begin{array}{l}\text { Experience (or } \\
\text { amount) of } \\
\text { participation in urban } \\
\text { renewal programs }\end{array}$ & 0.220 & $* * *$ & 0.065 & & - & $\begin{array}{l}\text { Hypothesis } 1 \\
\text { (supported) }\end{array}$ \\
\hline & $\begin{array}{c}\text { Level of the resident's } \\
\text { opinions reflected in } \\
\text { the project }\end{array}$ & 0.573 & $* * *$ & 0.549 & $* * *$ & $\begin{array}{l}\text { Experimental group } \\
>\text { Control group }\end{array}$ & $\begin{array}{l}\text { Hypothesis } 2 \\
\text { (supported) }\end{array}$ \\
\hline & $\begin{array}{l}\text { Need for urban } \\
\text { renewal } \\
\text { projects }\end{array}$ & 0.192 & $* *$ & 0.283 & $* * *$ & $\begin{array}{l}\text { Experimental group } \\
<\text { Control group }\end{array}$ & $\begin{array}{l}\text { Hypothesis } 3 \\
\text { (unsupported) }\end{array}$ \\
\hline $\begin{array}{l}\text { Neighborly } \\
\text { relation }\end{array}$ & Neighborly trust & 0.204 & $* *$ & 0.134 & * & $\begin{array}{l}\text { Experimental group } \\
>\text { Control group }\end{array}$ & $\begin{array}{l}\text { Hypothesis } 4 \\
\text { (supported) }\end{array}$ \\
\hline $\begin{array}{l}\text { Living } \\
\text { condition }\end{array}$ & $\begin{array}{l}\text { Level of satisfaction } \\
\text { with } \\
\text { living environments }\end{array}$ & 0.385 & $* * *$ & 0.047 & & - & - \\
\hline
\end{tabular}

Note: dependent variable $=$ resident satisfaction and expectation with urban renewal project, ${ }^{* * *} p<0.01,{ }^{* *} p<0.05,{ }^{*} p<0.1$

\section{Discussion}

This study focused on how local artists' participation affects local community networking and residents' satisfaction with culture-led regeneration projects by conducting a comparative analysis between the experimental and control groups. First, the variable, "experience (or amount) of participation in urban renewal programs", was significant only in Model 1. This variable refers to the frequency of participation experience in programs such as urban regeneration resident councils and at community schools. It implies the positive effects of involvement and activities of arts and cultural entities on resident satisfaction with the Changdong Art Village project. The Changwon urban regeneration resident council comprised residents who developed the content and programs for the arts and cultural projects via frequent discussions and sharing of opinions with local artists and cultural workers, as well as experts, as supporting entities of the project. Moreover, the urban regeneration community school systematically operated education programs that applied to arts and culture activities. Such active collaboration with artists and the use of arts and cultural content encouraged residents to participate in urban regeneration programs. Active participation in such programs may have also increased the residents will to achieve regional revitalization and understanding of the regeneration project. This result led to a significant positive effect on residents' satisfaction with urban regeneration projects and expected outcomes.

Second, the variables "reflection of residents' opinions" and "neighborly trust" were significant in both Models 1 and 2. Moreover, the relative effects of each variable on the dependent variable were higher in the experimental group. "Reflection of residents' opinions" (Model $1 \beta=0.573(p<0.01)>$ Model $2 \beta=0.549(p<0.01)$ refers to the reflection of residents' opinions on regeneration projects. "Neighborly trust" (Model $1 \beta=0.204(p<0.05)$ $>$ Model $2 \beta=0.134(p<0.1)$ represents the amicable awareness of residents' perceptions of their neighborship. The Changwon case had clear roles of entities and a network to gather opinions for arts and cultural projects. The two-way opinion gathering, information sharing, and supporting requests had continued since the beginning of the project. Artists, residents, and business owners could experience the process in which their opinions were presented, reflected, and implemented. Continuous discussions among the participating entities may 
have contributed to increasing not only the chance for residents to provide their opinions about the projects but also an actual reflection of their opinions. In other words, since there was relatively more active and collaborative sharing of opinions among participating entities in the experimental group than in the control group, Changwon residents may have perceived a higher level of "reflection of residents' opinions on regeneration projects" than the control group.

Based on the collaborative approach, in the Changwon case, seminars and interviews were conducted with various stakeholders (artists, residents, business owners, administration, Urban Regeneration Center, experts, etc.) to devise detailed contents of arts and cultural programs and discuss the direction of the project. Thus, Changwon residents could more extensively understand the positions of the other entities. Moreover, cultural content was more actively used in urban regeneration programs and education for residents, which is why the participating residents may have had smoother and easier interactions. This result may have had a positive effect on forming a neighborly trust. The residents could experience frequent communication with relevant entities, including artists. Furthermore, programs using arts and culture promoted actual participation and exchange among residents, thereby contributing to the formation of neighborhood trust, which is in line with Cha [11] and Kim et al.'s [12] work. In other words, increased residents' trust in the neighborship may have had a positive effect on satisfaction with urban regeneration projects and expected outcomes.

The "need for urban regeneration projects" refers to the extent to which residents feel that urban regeneration projects are needed. The relative effect of this variable was lower in the experimental group (Model $1 \beta=0.192(p<0.05)<$ Model $2 \beta=0.283(p<0.01$ ). Even in the effect of the significant variable in Model 1 in the experimental group, "need for urban regeneration projects" had the smallest effect on the dependent variable. This result implied that Changwon residents felt greater utility in "reflection of residents' opinions", "experience (or amount) of participation in urban renewal programs", and "neighborly trust" than "need for urban regeneration projects." It seems that establishing a cooperative system to present their opinions to various entities by participating in the process of actual regeneration projects and forming a neighborship may have a greater effect on improving residents' satisfaction with urban regeneration projects and expected outcomes.

Additionally, "satisfaction with the living environment" is residents' satisfaction with the overall living conditions, and this variable indicates satisfaction with the physical, environmental, social, and economic aspects of the area in which individuals live. Both the experimental group and control group showed outdated infrastructures, outflows and decreases in population numbers, and regional economic slumps. However, "satisfaction with the living environment" proved to be a significant variable only in the experimental group. Changwon actively used culture-led urban regeneration to renew the vitality of the area and set the direction for regional regeneration by gathering the opinions and needs of relevant entities (artists, residents, and business owners) as much as possible to maximize the cultural values of the area. In this process, Changwon residents may have had positive awareness of their living environments overall.

\section{Conclusions}

In this study, we aimed to determine how artists' participation affects residents' satisfaction with and expected outcomes of culture-led urban regeneration projects. We comparatively analyzed Model 1, focused on the experimental group (Changwon city) with active artist participation and operation of arts and cultural programs, and Model 2, focused on the control group (Sacheon, Gimhae, Miryang cities) with relatively inactive artist participation and operation of arts and cultural programs. The following conclusions were drawn.

First, the involvement and activities of arts and cultural entities in culture-led urban regeneration projects and the operation of arts and cultural programs increased residents' will to participate in regeneration projects, build neighborhood trust, and ultimately contribute 
to improving satisfaction with the living environment. This result has important ramifications for rejuvenating the old urban cities by adopting a cultural approach. Decision-makers and urban planners should consider a constructive system for local arts groups to provide productive supports. To deal with sustainable engagements and actions of artists in revitalized urban centers, several ways to support financial aids for artistic works, promote performances, and build a network with various parties can be developed.

Second, "reflection of residents' opinions" was the variable that had the greatest effect on residents' satisfaction with urban regeneration projects and expected outcomes in both Models 1 and 2, with the relative effect on the dependent variable being greater in Model 1. This suggests that reflecting residents' opinions on regeneration projects based on sufficient communication and discussion may greatly improve residents' satisfaction with urban regeneration projects and expected outcomes. Moreover, the relative effect was greater in Model 1 as the Changwon case showed smoother presentation and reflection of residents' opinions on urban regeneration projects mediated by artist participation and arts and cultural contents. The results of our analyses have provided empirical evidence about the relative significance of the various attributes. In the case of limited budgets, the outcomes indicate that policymakers can improve the effectiveness of urban renewal projects by focusing on a method to increase the level of residents' opinions on the projects. More practical actions and plans should be proposed to increase residents' participation and chances to share personal ideas on renewal projects. It can facilitate proper communication and cooperation among residents, artistic entities, design companies, and local governments and build consensus among them. By realizing active residents involvement and understanding their needs, this kind of culture-led renewal project can contribute to continuous regional revitalization, crucial for sustainable urban regeneration in Korea.

This study has significance in examining the effect of artist groups' involvement on resident satisfaction with urban regeneration projects and expected outcomes in Changwon, a noticeable case of culture-led urban regeneration in Korea; however, it has the following limitations. First, while selecting the experimental and control groups depending on artist participation and operation of arts programs in culture-led urban regeneration projects, we selected only one area as the experimental group and three areas to be a part of the control group. Future studies could select multiple cases for both the experimental and control groups. It would be possible to develop more general implications on resident satisfaction with culture-led urban regeneration. Second, there were limitations in collecting data. More than $72 \%$ of the respondents were above 40 years old. When collecting data, further research must gather more diverse residents' opinions from different age groups by using both site visits and online surveys. Lastly, future studies could consider more specified factors, not only including social aspects but also physical and economic aspects. This may help provide a deeper understanding of partnership with artists and residents, thus paving the way for a collaborative system explaining its impact on resident satisfaction with culture-led renewal projects.

Author Contributions: Y.B. conducted the literature reviews and wrote the first draft of the manuscript. C.J. contributed to suggestions and comments on the analytical framework. H.J. provided the survey data and helped with the improvement of the manuscript as the corresponding author. All authors contributed to modifying this manuscript. All authors have read and agreed to the published version of the manuscript.

Funding: This work was supported by the National Research Foundation of Korea (NRF) grant funded by the Korean Government (MSIT) 2020R1G1A1101214.

Institutional Review Board Statement: Not Applicable.

Informed Consent Statement: Informed consent was obtained from all subjects involved in the study. 
Data Availability Statement: The data presented in this study are available on request from the corresponding author. The data are not publicly available due to containing personal information.

Acknowledgments: The authors thank the anonymous reviewers and editors for their valuable and constructive suggestions for improving this article.

Conflicts of Interest: The authors declare no conflict of interest.

\section{Appendix A}

Table A1. Description of social-demographic data.

\begin{tabular}{|c|c|c|c|c|c|c|c|c|c|c|c|}
\hline \multirow{2}{*}{ Respondents } & \multicolumn{2}{|c|}{ Gender } & \multicolumn{5}{|c|}{ Age Group } & \multicolumn{4}{|c|}{ Ownership of Property } \\
\hline & Men & Women & $10 \mathrm{~s}$ & $30 \mathrm{~s}$ & $40 \mathrm{~s}$ & $50 \mathrm{~s}$ & $60 \mathrm{~s} \sim$ & & One's Own & Jeonse * & Rent \\
\hline (n) & 78 & 111 & 2 & 29 & 52 & 52 & 31 & & 127 & 36 & 26 \\
\hline$(\%)$ & 41.3 & 58.7 & 1.1 & 15.7 & 28.1 & 28.1 & 16.8 & & 67.2 & 19.0 & 13.8 \\
\hline \multirow[b]{2}{*}{ Respondents } & \multicolumn{6}{|c|}{ Residential Type } & \multicolumn{4}{|c|}{ Family Member } & Duration \\
\hline & $\begin{array}{l}\text { Detached } \\
\text { House }\end{array}$ & $\begin{array}{c}\text { Multi-Family } \\
\text { Residential }\end{array}$ & Apartment & $\begin{array}{c}\text { Studio } \\
\text { Apartment }\end{array}$ & $\begin{array}{r}F \\
\text { Abov }\end{array}$ & $\begin{array}{l}\text { ts } \\
\text { Retail }\end{array}$ & 1 & 2 & 3 & 4 & $\begin{array}{l}\text { rage } \\
\text { ear) }\end{array}$ \\
\hline (n) & 50 & 19 & 83 & 11 & & & 26 & 37 & 44 & 82 & 2 \\
\hline$(\%)$ & 26.5 & 10.1 & 43.9 & 5.8 & & & 13.8 & 19.6 & 23.3 & 43.4 & \\
\hline
\end{tabular}

Note: As 3 people did not respond to the gender question, 7 people to the age question, 3 people to the house ownership type question, 3 people to the housing type question, and 3 people to the family composition question, they were excluded from the analysis. ${ }^{*}$ Note: a Korean lump sum rental deposit (in place of a monthly rent) that is refunded at the end of the contract period.

\section{Appendix B}

Table A2. Results of factor analysis.

\begin{tabular}{|c|c|c|c|c|c|}
\hline \multirow[b]{2}{*}{ Dependent Variable } & \multirow[b]{2}{*}{ Questionnaire } & \multicolumn{3}{|c|}{ Factor Analysis } & \multirow{2}{*}{$\begin{array}{l}\text { Credibility } \\
\text { Cronbach's } \alpha\end{array}$} \\
\hline & & $\begin{array}{c}\text { Factor } \\
\text { Loadings }\end{array}$ & $\begin{array}{c}\text { SS } \\
\text { Loadings }\end{array}$ & $\begin{array}{l}\text { Proportion } \\
\text { Var. }\end{array}$ & \\
\hline \multirow{5}{*}{$\begin{array}{c}\text { Resident } \\
\text { satisfaction and } \\
\text { the expectation with } \\
\text { urban renewal } \\
\text { project }\end{array}$} & Satisfaction with urban renewal projects & 0.58 & \multirow{5}{*}{3.16} & \multirow{5}{*}{0.63} & \multirow{5}{*}{0.89} \\
\hline & Expectations for improving living & 0.85 & & & \\
\hline & Expectations for improving the local economy & 0.94 & & & \\
\hline & $\begin{array}{l}\begin{array}{l}\text { Expectations for improving neighborly } \\
\text { relations }\end{array}\end{array}$ & 0.75 & & & \\
\hline & Expectations for the result of the renewal project & 0.81 & & & \\
\hline
\end{tabular}

\section{Appendix C}

Table A3. Results of correlation analysis.

\begin{tabular}{|c|c|c|c|c|c|c|c|c|c|c|}
\hline & \multicolumn{2}{|c|}{ (1) } & \multicolumn{2}{|c|}{ (2) } & \multicolumn{2}{|c|}{ (3) } & \multicolumn{2}{|c|}{ (4) } & \multirow[t]{2}{*}{ (5) } & \multirow[t]{2}{*}{ (6) } \\
\hline $\begin{array}{l}\text { (1) Resident satisfaction and expectation with urban } \\
\text { renewal project }\end{array}$ & 1 & & & & & & & & & \\
\hline (2) Level of satisfaction with living environments & 0.220 & $* * *$ & 1 & & & & & & & \\
\hline (3) Neighborly trust & 0.392 & $* * *$ & 0.088 & & 1 & & & & & \\
\hline (4) Need for urban renewal projects & 0.407 & $* * *$ & 0.027 & & 0.136 & * & 1 & & & \\
\hline $\begin{array}{l}\text { (5) Level of the resident's opinions } \\
\text { reflected in the project }\end{array}$ & 0.695 & $* * *$ & 0.182 & $* *$ & 0.268 & $* * *$ & 0.196 & $* * *$ & 1 & \\
\hline $\begin{array}{l}\text { (6) Experience (or amount) of participation in urban } \\
\text { renewal programs }\end{array}$ & 0.198 & $* * *$ & -0.279 & & 0.183 & $* *$ & 0.193 & $* * *$ & 0.011 & 1 \\
\hline
\end{tabular}

Note: ${ }^{* * *} p<0.01,{ }^{* *} p<0.05,{ }^{*} p<0.1$. 


\section{References}

1. Hall, T.; Robertson, I. Public Art and Urban Regeneration: Advocacy, claims and critical debates. Landsc. Res. 2001, 26, 5-26. [CrossRef]

2. Ward, J. Down by the sea: Visual arts, artists and coastal regeneration. Int. J. Cult. Policy 2015, 24, 121-138. [CrossRef]

3. Chen, X.L.; Zhu, H.; Yuan, Z.J. Contested memory amidst rapid urban transition: The cultural politics of urban regeneration in Guangzhou, China. Cities 2020, 102, 102755. [CrossRef]

4. Goodey, B. Art-ful places: Public art to sell public spaces? In Place Promotion: The Use of Publicity and Marketing to Sell Towns and Regions; Wiley: Chichester, UK, 1994; pp. 153-179.

5. Korean Law Information Center. Available online: https:/ /www.law.go.kr/LSW/eng/engMain.do (accessed on 10 July 2021).

6. Urban Regeneration Information System. Available online: https:/ /www.city.go.kr/index.do (accessed on 3 June 2021).

7. Chung, H.; Kim, H. Revitalizing Urban Space and Cultivating Its Creativity by Culture and Arts: A Case Study of Seoul Art Spaces Geumcheon, Mullae, and Seogyo. Geogr. J. Korea 2011, 45, 279-293. (In Korean)

8. Kim, H.J. A Comparative Study on Creation Network of Mullae in Seoul, Daein Art Market in Gwangju, Totatoga in Busan. Seoul Stud. 2013, 14, 159-173. (In Korean)

9. Park, S.H. Can we implant an artist community? A reflection on government-led cultural districts in Korea. Cities 2016, 56, 172-179. [CrossRef]

10. Son, J.M. The Effect of Creative Space Supporting Project on The Artist's Continues The Intention to Move and Regional Revitalization: Focused on Totatoga in Busan. Master's Thesis, Hanyang University, Seoul, Korea, 2015. (In Korean).

11. Cha, D.I. A Study on the User's Consciousness about City Brand of Urban Regeneration: Focused on the Chang-dong Art Village in Chang-won. J. Brand Des. Assoc. Korea 2015, 13, 17-28. (In Korean)

12. Kim, K.Y.; Kim, Y.; Shin, J.W.; Kim, J.T. A Study on the Factor Analysis of Commercial Regeneration Strategy in Chang-won(Masan) City. J. Resid. Environ. Inst. Korea 2017, 15, 157-169. (In Korean) [CrossRef]

13. Park, J.-Y.; Son, J.-M.; Koo, J.-H. An Analysis of the Effect of the Support Program for Gwangju Dae-in Art Market on the Sustainable Activity Intent of Artists. J. Korea Plan. Assoc. 2019, 54, 5-14. [CrossRef]

14. Park, J.H.; Choi, Y. A Study on Retailers' Recognition about Commercial Power Altering Due to Urban Regeneration Project: Case of Changwon Urban Regeneration Priority Project. J. Korean Soc. Civ. Eng. 2018, 38, 771-782. [CrossRef]

15. Cho, H.K.; Shon, J.H. The regenerated old city center in Masan as the culture-led center: Focused on the case of Changwon Urban Regeneration Priority Project. Urban Plan. 2018, 5, 26-30. (In Korean)

16. Han, D.H. An Analysis on Characteristics of the Process of Creative City Formation through Urban Regeneration: Focusing on Dashanzi 798 Art Zone in Beijing and Chang-dong Art Village in Changwon. J. Gov. Stud. 2013, 8, 55-94. Available online: https:/ / www.kci.go.kr/kciportal/ci/sereArticleSearch/ciSereArtiView.kci?sereArticleSearchBean.artiId=ART001832448 (accessed on 3 June 2021). (In Korean).

17. Seo, I.J. An Empirical Analysis on the Type of Cultural Urban Regeneration: Focused on the Case of Masan Old Downtown in Changwon City. Resid. Environ. 2016, 14, 363-382. Available online: http://www.dbpia.co.kr/journal/articleDetail?nodeId= NODE07091971 (accessed on 3 June 2021). (In Korean)

18. Brown, A.; O'Connor, J.; Cohen, S. Local music policies within a global music industry: Cultural quarters in Manchester and Sheffield. Geoforum 2000, 31, 437-451. [CrossRef]

19. Haughton, G.; While, A. From corporate city to citizens city? Urban leadership after local entrepreneurialism in the United Kingdom. Urban Aff. Rev. 1999, 35, 3-23. [CrossRef]

20. Seo, U.S. Urban regeneration governance, community organizing, and artists' commitment: A case study of Seongbuk-dong in Seoul. City Cult. Soc. 2020, 21, 100328. [CrossRef]

21. Bobadilla, N.; Goransson, M.; Pichault, F. Urban entrepreneurship through art-based interventions: Unveiling a translation process. Entrep. Reg. Dev. 2018, 31, 378-399. [CrossRef]

22. Roberts, P.; Sykes, H. Urban Regeneration: A Handbook; Sage Publications: Thousand Oaks, CA, USA, 2008.

23. Jung, T.H.; Lee, J.; Yap, M.H.; Ineson, E.M. The role of stakeholder collaboration in culture-led urban regeneration: A case study of the Gwangju project, Korea. Cities 2015, 44, 29-39. [CrossRef]

24. Habermas, J.; Mccarthy, T.; Mccarthy, T. The Theory of Communicative Action; Beacon Press: Boston, MA, USA, 1984.

25. Healey, P. Planning through debate: The communicative turn in planning theory. Town Plan. Rev. 1992, 63, 143. [CrossRef]

26. Forester, J. Planning in the Face of Power; University of California Press: Berkeley, CA, USA, 1989.

27. Innes, J.E. Planning Theory's Emerging Paradigm: Communicative Action and Interactive Practice. J. Plan. Educ. Res. 1995, 14, 183-189. [CrossRef]

28. Friedmann, J. Retracking America: A Theory of Transactive Planning; Anchor Press: Norwell, MA, USA, 1973.

29. Healey, P. Collaborative Planning: Shaping Places in Fragmented Societies; Macmillan International Higher Education: London, UK, 1997.

30. Bäcklund, P.; Mäntysalo, R. Agonism and institutional ambiguity: Ideas on democracy and the role of participation in the development of planning theory and practice-the case of Finland. Plan. Theory 2010, 9, 333-350. [CrossRef]

31. Cheng, Y. Collaborative planning in the network: Consensus seeking in urban planning issues on the Internet-the case of China. Plan. Theory 2013, 12, 351-368. [CrossRef]

32. Forester, J. Critical Theory, Public Policy, and Planning Practice; SUNY Press: New York, NY, USA, 1993.

33. Sager, T. Communicative Planning Theory; Avebury: Aldershot, UK, 1994. 
34. Innes, J.E. Group Processes and the Social Construction of Growth Management: Florida, Vermont, and New Jersey. J. Am. Plan. Assoc. 1992, 58, 440-453. [CrossRef]

35. Healey, P. The communicative turn in planning theory and its implications for spatial strategy formations. Environ. Plan B Plan. Des. 1996, 23, 217-234. [CrossRef]

36. Ansell, C.; Gash, A. Collaborative governance in theory and practice. J. Public Adm. Res. Theory 2008, 18, 543-571. [CrossRef]

37. Emerson, K.; Nabatchi, T.; Balogh, S. An integrative framework for collaborative governance. J. Public Adm. Res. Theory 2012, 22, 1-29. [CrossRef]

38. Liu, L.; $\mathrm{Xu}, \mathrm{Z}$. Collaborative governance: A potential approach to preventing violent demolition in China. Cities 2018, 79, 26-36. [CrossRef]

39. Sørensen, E.; Torfing, J. Enhancing Collaborative Innovation in the Public Sector. Adm. Soc. 2011, 43, 842-868. [CrossRef]

40. Gerlak, A.K.; Heikkila, T. Building a Theory of Learning in Collaboratives: Evidence from the Everglades Restoration Program. J. Public Adm. Res. Theory 2011, 21, 619-644. [CrossRef]

41. Kort, M.; Klijn, E.-H. Public-Private Partnerships in Urban Regeneration Projects: Organizational Form or Managerial Capacity? Public Adm. Rev. 2011, 71, 618-626. [CrossRef]

42. Keating, M.; De Frantz, M. Culture-led strategies for urban regeneration: A comparative perspective on Bilbao. Int. J. Iber. Stud. 2004, 16, 187-194. [CrossRef]

43. Landry, C. The Creative City: A Toolkit for Urban Innovators; Earthscan: London, UK, 2012.

44. Florida, R. The Rise of the Creative Class; Basic Books: New York, NY, USA, 2002.

45. Landry, C.; Greene, L.; Matarasso, F.; Bianchini, F. The Art of Regeneration. In Urban Renewal through Cultural Activity; Stroud: Comedia: London, UK, 1996.

46. Nedučin, D.; Krklješ, M.; Gajić, Z. Post-socialist context of culture-led urban regeneration-Case study of a street in Novi Sad, Serbia. Cities 2019, 85, 72-82. [CrossRef]

47. Evans, G. Measure for Measure: Evaluating the Evidence of Culture's Contribution to Regeneration. Urban Stud. 2005, 42, 959-983. [CrossRef]

48. Ferilli, G.; Sacco, P.L.; Blessi, G.T.; Forbici, S. Power to the people: When culture works as a social catalyst in urban regeneration processes (and when it does not). Eur. Plan. Stud. 2016, 25, 241-258. [CrossRef]

49. Darchen, S.; Tremblay, D.-G. The local governance of culture-led regeneration projects: A comparison between Montreal and Toronto. Urban Res. Pr. 2013, 6, 140-157. [CrossRef]

50. Middleton, C.; Freestone, P. The impact of culture-led regeneration on regional identity in north east England. Reg. Urban Regen. Eur. Peripher. 2008, 51, 51-58.

51. Hui, E.C.M.; Chen, T.; Lang, W.; Ou, Y. Urban community regeneration and community vitality revitalization through participatory planning in China. Cities 2021, 110, 103072. [CrossRef]

52. Ponzini, D.; Rossi, U. Becoming a Creative City: The Entrepreneurial Mayor, Network Politics and the Promise of an Urban Renaissance. Urban Stud. 2010, 47, 1037-1057. [CrossRef]

53. Bridge, G. It's not just a question of taste: Gentrification, the neighbourhood, and cultural capital. Environ. Plan. A 2006, 38, 1965-1978. [CrossRef]

54. Smith, N. The New Urban Frontier: Gentrification and the Revanchist City; Psychology Press: Hove, UK, 1996.

55. Markusen, A. Urban Development and the Politics of a Creative Class: Evidence from a Study of Artists. Environ. Plan. A: Econ. Space 2006, 38, 1921-1940. [CrossRef]

56. Kim, J.Y. Cultural entrepreneurs and urban regeneration in Itaewon, Seoul. Cities 2016, 56, 132-140. [CrossRef]

57. Miles, S. "Our Tyne": Iconic Regeneration and the Revitalisation of Identity in NewcastleGateshead. Urban Stud. 2005, 42, 913-926. [CrossRef]

58. Ulldemolins, J.R. Culture and authenticity in urban regeneration processes: Place branding in central Barcelona. Urban Stud. 2014, 51, 3026-3045. [CrossRef]

59. Miles, S.; Paddison, R. Introduction: The Rise and Rise of Culture-led Urban Regeneration. Urban Stud. 2005, 42, 833-839. [CrossRef]

60. Wang, M. Place-making for the people: Socially engaged art in rural China. China Inf. 2018, 32, 244-269. [CrossRef]

61. Pratt, A. Urban Regeneration: From the Arts Feel Good' Factor to the Cultural Economy: A Case Study of Hoxton, London. Urban Stud. 2009, 46, 1041-1061. [CrossRef]

62. García, B. Urban Regeneration, Arts Programming And Major Events. Int. J. Cult. Policy 2004, 10, 103-118. [CrossRef]

63. Bailey, C.; Miles, S.; Stark, P. Culture-Led Urban Regeneration and The Revitalisation of Identities in Newcastle, Gateshead and the North East of England. Int. J. Cult. Policy 2004, 10, 47-65. [CrossRef]

64. Hur, M.; Nasar, J.L.; Chun, B. Neighborhood satisfaction, physical and perceived naturalness and openness. J. Environ. Psychol. 2010, 30, 52-59. [CrossRef]

65. Basolo, V.; Strong, D. Understanding the neighborhood: From residents' perceptions and needs to action. Hous. Policy Debate 2002, 13, 83-105. [CrossRef]

66. Campbell, A.; Converse, P.E.; Rodgers, W.L. The Quality of American Life: Perceptions, Evaluations, and Satisfactions; Russell Sage Foundation: New York, NY, USA, 1976. Available online: https://books.google.com/books?id=h_QWAwAAQBAJ (accessed on 3 June 2021). 
67. Mohan, J.; Twigg, L. Sense of Place, Quality of Life and Local Socioeconomic Context: Evidence from the Survey of English Housing, 2002/03. Urban Stud. 2007, 44, 2029-2045. [CrossRef]

68. Gruber, K.J.; Shelton, G.G. Assessment of neighborhood satisfaction by residents of three housing types. Soc. Indic. Res. 1987, 19, 303-315. [CrossRef]

69. Austin, D.M.; Baba, Y. Social determinants of neighborhood attachment. Sociol. Spectr. 1990, 10, 59-78. [CrossRef]

70. Dassopoulos, A.; Monnat, S.M. Do Perceptions of Social Cohesion, Social Support, and Social Control Mediate the Effects of Local Community Participation on Neighborhood Satisfaction? Environ. Behav. 2011, 43, 546-565. [CrossRef]

71. Kim, K.S. The Effect of Urban Regeneration on the Village Satisfaction and Community Spirit of the Citizens of Seoul. Korean Assoc. Public Soc. 2014, 4, 66-92. (In Korean)

72. Suh, N.J.; Kim, H.C. A Study on the Determinants of Residents' Satisfaction in Urban Regeneration Projects: Focused on Urban Vitality Promotion Projects. Korea Real Estate Soc. 2019, 53, 25-46. (In Korean)

73. Chang-dong Art Village. Available online: http:/ / changdongartvillage.kr (accessed on 3 June 2021).

74. Changwon City Urban Regeneration Center. Available online: http:/ / www.cwurc.or.kr (accessed on 3 June 2021).

75. Joo, H.S.; Ma, S.R.; Jo, J.H. Strategies of Urban Regeneration Considering the Contexts of South Gyeongsang Province; Gyeongnam Institute: Sacheon, Korea, 2019; pp. 1-450. (In Korean)

76. The Revitalization Plan of Changwon Urban Regeneration Project; Ministry of Environment and Urban Affairs Bureau: Changwon, Korea, 2014. (In Korean)

77. Kim, T.D.; Sung, S.A.; Hwang, H.Y. Comparative resident satisfaction studies between Changwon and Cheongju regener-ation projects. J. Environ. Policy Adm. 2014, 22, 153-181. (In Korean)

78. Choi, M.G.; Hwang, H.Y. Effects of Collaborative Governance on the Residents Satisfaction Level in Self-Help Residential Regeneration Projects: Focused on Cheong-Ju Sajik 2-Dong. Korean Reg. Dev. Assoc. 2014, 26, 207-228. (In Korean)

79. Kang, M.H.; Song, H.S. A Study on Factors Affecting Satisfaction with Urban Regeneration Project between Participants: Focused on the Resident Group and Expert Group in Urban Regeneration Areas in Seoul. J. Archit. Inst. Korea Plan. Des. 2017, $33,3137$. (In Korean)

80. Nachmias, C.; Palen, J. Neighborhood satisfaction, expectations, and urban revitalization. J. Urban Aff. 1986, 8, 51-62. [CrossRef]

81. Wolpert, J. Migration as an Adjustment to Environmental Stress. J. Soc. Issues 1966, 22, 92-102. [CrossRef]

82. Speare, A. Residential Satisfaction as an Intervening Variable in Residential Mobility. Demography 1974, 11, 173-188. [CrossRef]

83. Brown, L.A.; Moore, E.G. The intra-urban migration process: A perspective. Geogr. Ann. Ser. B Hum. Geogr. 1970, 52, 1-13. [CrossRef]

84. Permentier, M.; Bolt, G.; Van Ham, M. Determinants of neighbourhood satisfaction and perception of neighbourhood reputa-tion. Urban Stud. 2011, 48, 977-996. [CrossRef]

85. Grogan-Kaylor, A.; Woolley, M.; Mowbray, C.; Reischl, T.M.; Gilster, M.; Karb, R.; Macfarlane, P.; Gant, L.; Alaimo, K. Predictors of Neighborhood Satisfaction. J. Community Pract. 2006, 14, 27-50. [CrossRef] 